\title{
Effect of Nitrogen Rate on Plant Nitrogen Loss in Winter Wheat Varieties
}

\author{
Fred K. Kanampiu, William R. Raun, \\ Gordon V. Johnson and M.P. Anderson
}

\begin{abstract}
Gaseous nitrogen (N) loss from winter wheat (Triticum aestivum L.) plants has been identified but has not been simultaneously evaluated for several genotypes grown under different $N$ fertility. Two field experiments were initiated in 1993 and 1994 at the Agronomy Research Station in Stillwater and Perkins to estimate plant $\mathbf{N}$ loss from several cultivars as a function of $\mathbf{N}$ applied and to characterize $\mathrm{N}$ use efficiency (NUE). A total of five cultivars were evaluated at preplant $N$ rates ranging from 30 to $180 \mathrm{~kg} \mathrm{ha}^{-1}$. Nitrogen loss was estimated as the difference between total forage $\mathbf{N}$ accumulated at anthesis and the total (grain + straw) $\mathrm{N}$ at harvest. Forage, grain, straw yield, $\mathrm{N}$ uptake, and $\mathrm{N}$ loss increased with increasing $\mathbf{N}$ applied at both Stillwater and Perkins. Significant differences were observed among varieties for yield, $N$ uptake, $N$ loss and components of NUE in forage, grain, straw and grain + straw. Estimates of $\mathbf{N}$ loss over this two year period ranged from 4.0 to $27.9 \mathrm{~kg} \mathrm{ha}^{-1}$ (7.7 to $59.4 \%$ of total forage $\mathrm{N}$ at anthesis). Most $\mathrm{N}$ losses occurred between anthesis and 14 days post-anthesis. Avoiding excess $\mathrm{N}$ application would reduce $\mathbf{N}$ loss and increase NUE in winter wheat varieties. Varieties with high harvest index (grain yield/total biomass) and low forage yield had low plant $\mathrm{N}$ loss. Estimates of plant loss suggest $\mathbf{N}$ balance studies should consider this variable before assuming that unaccounted $\mathbf{N}$ was lost to leaching and denitrification.
\end{abstract}

\section{INTRODUCTION}

W orldwide interest associated with increasing cereal grain protein has focused added attention on improving the utilization of $\mathrm{N}$ in cereals (Desai and Bhatia, 1978). The effectiveness with which $\mathrm{N}$ is used by wheat and other cereals has become increasingly important because of increased costs associated with the manufacture and distribution of $\mathrm{N}$ fertilizer. Increased use of fertilizer $\mathrm{N}$ in agricultural production has raised concerns because of the potential for groundwater contamination. This concern has pressured farmers to use $\mathrm{N}$ more efficiently.

Nitrogen use efficiency is defined as grain production per unit of $\mathrm{N}$ available in the soil (Moll et al., 1982; Van Sanford and Mackown, 1986). Nitrogen uptake and partitioning between straw and grain are the two major components of $\mathrm{N}$ economy in plants (Desai and Bhatia, 1978). Partitioning $\mathrm{N}$ between grain and straw is important in cereal crops that are grown in areas with depleted soil $\mathrm{N}$ and moisture during the grain filling period. Uptake efficiency (total shoot $\mathrm{N} /$ soil $\mathrm{N}$ supply) and utilization (grain yield/total shoot $\mathrm{N}$ ) of $\mathrm{N}$ in the production of grain requires that the processes of uptake, translocation, assimilation, and redistribution of $\mathrm{N}$ operate effectively. The relative contribution of these processes to genotypic differences in NUE is unknown and varies among genetic populations and among environments, including $\mathrm{N}$ supply. Moll et al. (1982) observed an interaction between corn hybrids and $\mathrm{N}$ levels for all traits except grain yield. At low $\mathrm{N}$ supply, differences among hybrids for NUE were 
largely due to variation in utilization of accumulated $\mathrm{N}$, but with high $\mathrm{N}$ they were largely due to variation in uptake efficiency. They concluded that variation of NUE appeared to result from differences among genotypes and levels of $\mathrm{N}$ supplied.

Wuest and Cassman (1992) found recovery of $\mathrm{N}$ applied at planting ranged from 30 to $55 \%$, while recovery of $\mathrm{N}$ applied at anthesis ranged from 55 to $80 \%$ in irrigated wheat. The amount of fertilizer $\mathrm{N}$ applied at anthesis had the greatest influence on post-anthesis $\mathrm{N}$ uptake, which ranged from 17 to $77 \mathrm{~kg} \mathrm{~N}$ $\mathrm{ha}^{-1}$. This shows that late $\mathrm{N}$ application can be efficiently taken up by plants. Grain protein levels may increase with late-season $\mathrm{N}$ applications (Wuest and Cassman, 1992). Fertilizer $\mathrm{N}$ use efficiency varies considerably depending upon the native soil $\mathrm{N}$ supply, previous $\mathrm{N}$ uptake, developmental stage of the plant when supplemental $\mathrm{N}$ is applied, and yield potential (Wuest and Cassman, 1992). Optimizing fertilizer $\mathrm{N}$ use, achieving acceptable grain yield, and maintaining adequate grain protein requires knowledge of expected $\mathrm{N}$ uptake efficiency and utilization within the plant in relation to the rate and timing of $\mathrm{N}$ applied.

Calculation of $\mathrm{N}$ fertilizer use efficiency is typically based on the amount of $\mathrm{N}$ found in the crop at maturity. It is commonly perceived that maximum accumulation of $\mathrm{N}$ by plants occurs at maturity; however, it is more typical for maximum $\mathrm{N}$ accumulation of grain crops to be reached sometime between pollination and maturity (Francis, 1993a). Dhugga and Waines (1989) found differences among wheat genotypes for shoot $\mathrm{N}$ accumulation before and after anthesis at the highest soil $\mathrm{N}$ level. At this level, some genotypes either stopped accumulating or showed a net loss of shoot $\mathrm{N}$ between anthesis and maturity, which appeared to be associated with superior preanthesis $\mathrm{N}$ accumulation capacity and reduced grain $\mathrm{N}$ yield of such genotypes.

Plant shoots may be a significant source of $\mathrm{N}$ loss in crops. Volatile $\mathrm{N}$ has been found to be released from plant tissue with $\mathrm{NH}_{3}$ being the prevalent form of post-anthesis N loss (Harper et al., 1987). Francis et al. (1993b) found maximum net $\mathrm{N}$ accumulation in corn to occur during early reproductive development (R1 R3) followed by a subsequent decline. They found plant $\mathrm{N}$ loss could account for 52 to $73 \%$ of the unaccounted $\mathrm{N}$ in $15 \mathrm{~N}$ balance calculations. Ammonia loss rates on a leaf-area basis from wheat were found to be similar for low and high $\mathrm{N}$ plants despite significantly high $\mathrm{N}$ concentrations in high $\mathrm{N}$ plants (Parton et al., 1988). They found twice the leaf area was attained by the high $\mathrm{N}$ plants, resulting in $\mathrm{NH}_{3}$ volatilization rates roughly twice those observed in the low- $\mathrm{N}$ plants. Nitrogen loss from wheat plants through aerial $\mathrm{NH}_{3}$ transport has also been found during periods of adequate available soil $\mathrm{N}$ (Harper et al., 1987) and during plant senescence (Harper et al., 1987; Parton et al., 1988). Harper et al. (1987) found largest aerial loss to occur during a 20-day period after fertilizer application (11.4\% of the applied fertilizer) while additional losses $(9.8 \%)$ were observed from anthesis to harvest. The former aerial $\mathrm{NH}_{3}$ losses could have been due to overloading of plant $\mathrm{N}$ as $\mathrm{NH}_{4}{ }^{+}$whereas the latter could be due to plant senescence and inefficient redistribution of $\mathrm{N}$ within the plant. High $\mathrm{N}$ fertility levels often increase leaf area indices, but the greatest difference during 
maturation is the ability to maintain a larger number of green leaves late in the season as compared with low $\mathrm{N}$ fertility levels. Plant $\mathrm{N}$ losses could account for much of the $\mathrm{N}$ losses found in soil $\mathrm{N}$ balance studies and certainly influence calculations involving fertilizer $\mathrm{N}$ efficiency (Daigger et al., 1976). Failure to include direct plant $\mathrm{N}$ losses when calculating an $\mathrm{N}$ budget can lead to overestimation of losses from the soil by denitrification, leaching, and ammonia volatilization (Francis et al., 1993b). Proper accounting for volatile plant $\mathrm{N}$ losses may play an important role in developing cropping systems that have improved $\mathrm{N}$ fertilizer use efficiencies and reduced environmental impact.

Remobilization of vegetative $\mathrm{N}$ during grain fill in wheat contributes significantly to final grain N content. Van Sanford and Mackown (1987), working with soft red winter wheat, detected significant cultivar differences in $\mathrm{N}$ remobilization from the flag leaf, peduncle, and lower culm. The proportion of $\mathrm{N}$ accumulated by the spike ranged among cultivars from 51 to $91 \%$. They also found $83 \%$ of the total above ground $\mathrm{N}$ at maturity to be present in the plant at anthesis. An analysis of cultivar differences indicated that all of the cultivar variation in final spike $\mathrm{N}$ could be associated with variation in total $\mathrm{N}$ uptake. Higher post-anthesis $\mathrm{N}$ uptake was associated with lower $\mathrm{N}$ utilization efficiency (spike weight/total plant $\mathrm{N}$ ), higher grain $\mathrm{N}$ concentration, and lower grain yields (Van Sanford and Mackown, 1987).

Although soil fertility research programs have been successful in establishing fertilizer $\mathrm{N}$ optimums for selected wheat varieties, little work has been done to improve genetic NUE in wheat. Therefore, plant breeders need to develop cultivars that can absorb $\mathrm{N}$ more efficiently from the soil and effectively partition absorbed $\mathrm{N}$ to the grain. Such cultivars could minimize loss of $\mathrm{N}$ from the soil and make more economic use of the absorbed N (Dhugga and Waines, 1989). Because crop fertilizer recovery seldom exceeds $50 \%$, the potential for increasing NUE has stimulated new research. It is the unaccounted portion in the crop that is currently being addressed in research. Effective use of applied $\mathrm{N}$ by the crop will reduce input costs per unit of product harvested. Identification of $\mathrm{N}$ use efficient wheat varieties could decrease $\mathrm{N}$ fertilizer requirements and limit the potential for $\mathrm{NO}_{3}-\mathrm{N}$ leaching losses. More studies are required to identify wheat varieties which maintain high yield potential with lower $\mathrm{N}$ fertilizer requirements.

The objective of this research was to estimate plant $\mathrm{N}$ loss from several wheat cultivars and experimental populations as a function of $\mathrm{N}$ applied and to characterize nitrogen use efficiency.

\section{MATERIALS AND METHODS}

Two field experiments were initiated in October 1993 and 1994 at the Agronomy Research Station in Stillwater and Perkins, OK to estimate plant $\mathrm{N}$ loss from several wheat cultivars as a function of $\mathrm{N}$ applied, and to characterize NUE as affected by time of $\mathrm{N}$ fertilization. Four wheat varieties (Karl, 2180, TAM W-101, and Chisholm) were evaluated at both locations. In addition to these four, 'Longhorn' was also evaluated at Perkins. At both locations, plot sizes were $1.13 \times 15.2 \mathrm{~m}$ (5 rows/plot). All cultivars and experimental populations were 
evaluated at preplant $\mathrm{N}$ rates of $0,30,60$ and $120 \mathrm{~kg} \mathrm{ha}^{-1}$ (Stillwater) and 0,45 , 90 and $180 \mathrm{~kg} \mathrm{ha}^{-1}$ (Perkins). Urea ammonium nitrate (UAN, 28-0-0) was used as the $\mathrm{N}$ source applied at planting for all $\mathrm{N}$ treatments. A complete factorial arrangement of treatments was used ( $\mathrm{N}$ rate $\mathrm{x}$ genotype) in a randomized complete block experimental design with four and three replications for Stillwater and Perkins, respectively. Soil classification, initial soil characteristics, harvest areas and harvest dates are reported for Stillwater and Perkins in Tables 1 and 2. Sufficient area was available in each plot to accommodate forage harvest and grain yield in separate areas of each plot. Forage harvests were obtained by hand clipping all plants $2 \mathrm{~cm}$ above the ground at anthesis. Subsamples from each respective harvest were collected for moisture and total $\mathrm{N}$ analysis. All forage and grain samples were ground in a large Wiley mill and later in an automated grinding unit to obtain finely ground forage, grain and straw subsamples. Total $\mathrm{N}$ was determined on forage, grain and straw samples using a Carlo-Erba NA 1500 dry combustion analyzer (Schepers et al., 1989). Nitrogen use efficiency was analyzed according to an expanded model of Moll et al. (1982). Nitrogen use efficiency for grain yield was partitioned into various components as follows:

$\mathrm{Gw} / \mathrm{Ns}=$ grain weight/N supply

$\mathrm{Gw} / \mathrm{Ns}=(\mathrm{Nt} / \mathrm{Ns})(\mathrm{Gw} / \mathrm{Nt})$, where

$\mathrm{Nt} / \mathrm{Ns}=$ uptake efficiency $=$ ratio of total plant to $\mathrm{N}$ supply per unit area, leaves),

$\mathrm{Nt}=($ grain yield $)($ grain $\mathrm{N})+($ dry wt of stem and leaves $)(\mathrm{N}$ in stem and

$\mathrm{Gw} / \mathrm{Nt}=$ utilization efficiency $=(\mathrm{Gw} / \mathrm{Ng})(\mathrm{Ng} / \mathrm{Nt})$, where

$\mathrm{Gw} / \mathrm{Ng}=$ grain weight/grain $\mathrm{N}$ and

$\mathrm{Ng} / \mathrm{Nt}=$ translocation efficiency $=$ proportion of total plant $\mathrm{N}$ in the grain .

Nitrogen loss was estimated as the difference between total forage $\mathrm{N}$ accumulated at anthesis and the total (grain + straw) $\mathrm{N}$ at harvest. Data analysis was performed using SAS (SAS Institute Inc., 1988). Means were compared using Student-Newman-Keuls' (SNK) test at the 5\% significance level.

\section{RESULTS AND DISCUSSION}

At both locations, forage, grain and straw yield, and forage, grain, straw and grain + straw $\mathrm{N}$ uptake increased with increasing $\mathrm{N}$ applied (Tables 3 and 4). The exception to this was noted for straw yield at Stillwater. Interpretation of $\mathrm{N}$ rate and variety main effects was simplified at Stillwater since no $\mathrm{N}$ rate by variety interactions were found for any of the measured dependent variables (Table 3). At Perkins a highly significant $\mathrm{N}$ rate by variety interaction was found for grain and straw yield, and straw and grain + straw $\mathrm{N}$ uptake, thus restricting interpretation of main effect means (Table 4). At both locations there were differences among varieties for forage, grain and straw yield and forage, grain, straw and grain + straw N uptake. The cultivars Chisholm and TAM W-101 both had high yield and $\mathrm{N}$ uptake in forage, grain and grain + straw compared with other varieties at Stillwater. At Perkins, Chisholm, Karl, 2180 and Longhorn 
(which was not included at Stillwater) had high yield and $\mathrm{N}$ uptake in forage and grain.

Excluding NUE at Perkins, no $\mathrm{N}$ rate by variety interactions were found for $\mathrm{N}$ use efficiency variables (Tables 5 and 6 ). Increased fertilizer $\mathrm{N}$ generally decreased NUE, N uptake efficiency, $\mathrm{N}$ utilization efficiency, fraction of $\mathrm{N}$ translocated to grain and grain yield per grain $\mathrm{N}$, but increased protein content and $\mathrm{N}$ loss (Tables 5 and 6 ). However, the increase in fraction of $\mathrm{N}$ translocated to the grain with increased fertilizer $\mathrm{N}$ at Perkins was not significant. Generally, percent protein and $\mathrm{N}$ loss were lower at Stillwater when compared to Perkins. The opposite was observed for other NUE components. Nitrogen loss ranged from 4.0 to 17.1 and 21.8 to $27.9 \mathrm{~kg} \mathrm{ha}^{-1}$ (averaged over $\mathrm{N}$ rates) at Stillwater and Perkins, respectively. In terms of the proportion of $\mathrm{N}$ accumulated in the plants at anthesis, $\mathrm{N}$ loss ranged from 7.7 to $30.0 \%$ and 53.2 to $59.4 \%$ at Stillwater and Perkins, respectively. Similar results of $\mathrm{N}$ loss from wheat plants through aerial $\mathrm{NH}_{3}$ transport have also been found during periods when there is adequate available soil $\mathrm{N}$ (Harper et al., 1987).

Except for percent protein, grain yield per grain $\mathrm{N}$ and $\mathrm{N}$ loss at Stillwater and $\mathrm{N}$ utilization efficiency and $\mathrm{N}$ loss at Perkins, the varieties evaluated showed differences in NUE components (Tables 5 and 6). At Stillwater, Chisholm and TAM W-101 had higher NUE, N uptake efficiency and N utilization efficiency whereas at Perkins 2180 and Longhorn had higher $\mathrm{N}$ use and $\mathrm{N}$ uptake efficiency compared to other varieties evaluated. These results agree with the work of Daigger et al. (1976) and Dhugga and Waines (1989) who found differences among wheat genotypes for shoot $\mathrm{N}$ accumulation before and after anthesis. Differences between varieties were also found at various $\mathrm{N}$ rates for grain and straw yield, and straw and grain + straw $\mathrm{N}$ uptake and $\mathrm{N}$ use efficiency at Perkins (Table 7). Similar differences were found for NUE at Stillwater. All evaluated varieties showed a decrease in $\mathrm{N}$ uptake between anthesis and maturity at Perkins (Figure 1). Longhorn and 2180 had the highest $\mathrm{N}$ loss and Karl had the lowest. The loss was greater between anthesis and 14 days postanthesis as compared to 14 days post-anthesis and maturity. This suggests that most $\mathrm{N}$ losses occurred prior to and early in the grain filling period when $\mathrm{N}$ is rapidly translocated from other plant parts to the head. During anthesis, protein in stems and leaves is degraded to its constituent amino acids and/or $\mathrm{NH}_{3}$. Ammonia assimilation occurs to incorporate the released $\mathrm{N}$ into amino acids. Depending on various factors such as temperature, light, wind, moisture, $\mathrm{pH}$ among others, $\mathrm{NH}_{3}$ formed during protein degradation can be lost from the plant by volatilization. Results from response surface modeling suggest that $\mathrm{N}$ loss increases with increasing forage yield and percent forage N. This indirectly suggests that cultivars with a high harvest index (grain yield/total biomass) and low forage yield will have low plant $\mathrm{N}$ loss. Estimates of plant $\mathrm{N}$ loss in this work also suggest that $\mathrm{N}$ balance studies should consider this variable before assuming that all unaccounted $\mathrm{N}$ was lost to leaching or denitrification.

It is important to note that estimates of plant $\mathrm{N}$ loss in this work have likely been underestimated since soil $\mathrm{N}$ uptake and plant $\mathrm{N}$ loss are dynamic processes which occur as the plant grows towards maturity. This is because our 
work did not identify the exact date (physiological stage) where $\mathrm{N}$ accumulated in wheat was at a maximum. Based on the literature cited, flowering was the best estimate for maximum $\mathrm{N}$ accumulation in wheat (Daigger et al., 1976). In addition, plant $\mathrm{N}$ loss as estimated here assumes that no added soil $\mathrm{N}$ uptake took place beyond flowering. This is somewhat unrealistic since we know that the wheat plant continues to assimilate soil $\mathrm{N}$ beyond flowering (Harper et al., 1987). Therefore continued plant loss of additional assimilated soil N (beyond flowering) would not be accounted for using our methods.

\section{CONCLUSIONS}

Forage, grain, straw, total yield and $\mathrm{N}$ uptake, and $\mathrm{N}$ loss were significantly increased with increasing $\mathrm{N}$ applied. Nitrogen loss ranged from 4.0 to 26.3 and 11.2 to $27.9 \mathrm{~kg} \mathrm{ha}^{-1}$ (averaged over $\mathrm{N}$ rates) at Stillwater and Perkins, respectively. Avoiding excess $\mathrm{N}$ application could reduce $\mathrm{N}$ losses and increase NUE in winter wheat varieties. Estimates of plant $\mathrm{N}$ loss from anthesis to 14 days post-anthesis were greater than that from 14 days post-anthesis to maturity. Results from response surface modeling suggest that $\mathrm{N}$ loss increased with increasing forage yield and percent forage N. This indirectly indicates that varieties with a high harvest index and low forage yield may have low plant $\mathrm{N}$ loss. Estimates of plant loss in this work suggest $\mathrm{N}$ balance studies should consider this variable before assuming that all unaccounted $\mathrm{N}$ was lost to leaching and denitrification.

\section{REFERENCES}

Daigger, L.A., D.H. Sander, and G.A. Peterson. 1976. Nitrogen content of winter wheat during growth and maturation. Agron. J. 68:815-818.

Dhugga, K.S. and J.G. Waines. 1989. Analysis of nitrogen accumulation and use in bread and durum wheat. Crop Sci. 29:1232-1239.

Desai, R.M. and C.R. Bhatia. 1978. Nitrogen uptake and nitrogen harvest index in durum wheat cultivars varying in their grain protein concentration. Euphytica. 27:561-566.

Francis, D. 1993a. Nitrogen loss from corn plants during grain fill. Better crops. p.16-19.

Francis, D.D., J.S. Schepers, and M.F. Vigil. 1993b. Post-anthesis nitrogen loss from corn. Agron. J. 85:659-663.

Harper, L.A., R.R. Sharpe, G.W. Langdale, and J.E. Giddens. 1987. Nitrogen cycling in a wheat crop: soil, plant, and aerial nitrogen transport. Agron. J. 79:965-973.

Moll, R.H., E.J. Kamprath, and W.A. Jackson. 1982. Analysis and interpretation of factors which contribute to efficiency of nitrogen utilization. Agron. J. 74:562-564.

Parton, W.J., J.A. Morgan, J.M. Allenhofen, and L.A. Harper. 1988. Ammonia volatilization from spring wheat plants. Agron. J. 80:419-425.

SAS Institute Inc. 1988. SAS procedures guide for personal computers, version 6 Edition. SAS institute Inc., Cary, NC, USA.

Schepers, J.S., D.D Francis, and M.T. Thompson. 1989. Simultaneous determination of total C, total N, and $15 \mathrm{~N}$ on soil and plant material. Commun. in Soil Sci. Plant Anal. 20:949-959. 
Van Sanford, D.A. and C.T. Mackown. 1986. Variation in nitrogen use efficiency among soft red winter wheat genotypes. Theor. Appl. Genet. 72:158-163.

Van Sanford, D.A. and C.T. Mackown. 1987. Cultivar differences in nitrogen remobilization during grain fill in soft red winter wheat. Crop Sci. 27:295-300.

Wuest, S.B. and K.G. Cassman. 1992. Fertilizer-nitrogen use efficiency of irrigated. wheat: I. Uptake efficiency of preplant versus late-season application. Agron. J. 84:682-688. 
Table 1. Soil Chemical Characteristics and Classification at Stillwater and Perkins, OK.

\begin{tabular}{|c|c|c|c|c|c|c|c|}
\hline Location & $\mathrm{pH}$ & $\mathrm{NH}_{4}-\mathrm{N}$ & $\mathrm{NO}_{3}-\mathrm{N}$ & $\mathrm{P}$ & $\mathrm{K}$ & Total N & Organic C \\
\hline & \multicolumn{5}{|c|}{ 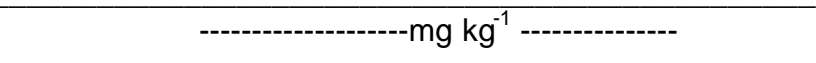 } & \multicolumn{2}{|c|}{---- $\mathrm{g} \mathrm{kg}^{-1}$} \\
\hline \multicolumn{8}{|c|}{ Classification: Kirkland silt loam (fine-mixed, thermic Udertic Paleustoll) } \\
\hline $\begin{array}{l}\text { Perkins } \\
\text { Classificat }\end{array}$ & $\begin{array}{l}6.0 \\
\text { ler sa }\end{array}$ & $\begin{array}{l}19.1 \\
\mathrm{n} \text { (fine-lc }\end{array}$ & $\begin{array}{l}6.5 \\
y, \text { mixed, }\end{array}$ & $\begin{aligned} & 11.8 \\
& \operatorname{mic} U\end{aligned}$ & $\begin{array}{r}29.5 \\
\text { ustoll) }\end{array}$ & 0.66 & 7.4 \\
\hline
\end{tabular}

Table 2. Planting and Harvest Dates, Stillwater and Perkins, OK.

\begin{tabular}{|c|c|c|}
\hline & Stillwater & Perkins \\
\hline Planting date: & October 27, 1993 & October 24, 1994 \\
\hline $\begin{array}{l}\text { Forage at anthesis: } \\
\text { harvest area } \\
\text { harvest date }\end{array}$ & $\begin{array}{l}0.91 \times 4.6 \mathrm{~m} \\
\text { May } 12 \mathrm{th}, 1994\end{array}$ & $\begin{array}{l}0.45 \times 3 \mathrm{~m} \\
\text { April 24th, } 1995\end{array}$ \\
\hline $\begin{array}{l}\text { Forage at post-anthesis: } \\
\text { harvest area } \\
\text { harvest date }\end{array}$ & $\begin{array}{l}\text { NA } \\
\text { NA }\end{array}$ & $\begin{array}{l}0.45 \times 3 \mathrm{~m} \\
\text { May 8th, } 1995\end{array}$ \\
\hline $\begin{array}{l}\text { Grain: } \\
\text { harvest area: } \\
\text { harvest date: }\end{array}$ & $\begin{array}{l}1.14 \text { x } 10.6 \mathrm{~m} \\
\text { June 20th, } 1994\end{array}$ & $\begin{array}{l}1.13 \times 9 \mathrm{~m} \\
\text { June 14th, } 1995\end{array}$ \\
\hline $\begin{array}{l}\text { Straw: } \\
\text { harvest area: } \\
\text { harvest date: }\end{array}$ & $\begin{array}{l}1.14 \text { x } 10.6 \mathrm{~m} \\
\text { June 20th, } 1994\end{array}$ & $\begin{array}{l}1.13 \text { × } 9 \text { m } \\
\text { July } 14 \text { th, } 1995\end{array}$ \\
\hline
\end{tabular}


Table 3. Analysis of Variance, Means and Comparisons for Yield and Nitrogen Uptake, Stillwater, OK 1994.

\begin{tabular}{|c|c|c|c|c|c|c|c|c|}
\hline \multirow{5}{*}{$\begin{array}{l}\text { Source of variation } \\
\text { Replication } \\
\mathrm{N} \text { rate }\end{array}$} & \multirow{3}{*}{ df } & Forage & \multirow{3}{*}{\multicolumn{2}{|c|}{$\begin{array}{l}\text { Grain } \\
\text { yield, } \mathrm{Mg}_{\mathrm{h}}{ }^{-1}\end{array}$}} & Forage & \multirow{2}{*}{\multicolumn{2}{|c|}{$\begin{array}{ll}\text { Grain } & \text { Straw } \\
\text { nitrogen uptake, } \mathrm{Mg} \mathrm{ha}^{-1}\end{array}$}} & \multirow{2}{*}{ (Grain + Straw) } \\
\hline & & \multirow{2}{*}{\multicolumn{4}{|c|}{---1 }} & & & \\
\hline & & & & & & & & \\
\hline & 3 & $21.2^{* \star}$ & $0.3 \mathrm{~ns}$ & $0.1 \mathrm{~ns}$ & $0.008^{* *}$ & $0.0002 \mathrm{~ns}$ & $0.0002^{\star *}$ & $0.0008^{*}$ \\
\hline & 3 & $11.1^{* *}$ & $1.8^{* *}$ & $0.3 n s$ & $0.004^{\star *}$ & $0.001^{* *}$ & $0.00002^{*}$ & $0.002^{* *}$ \\
\hline Variety & 3 & $4.2^{\star \star}$ & $4.4^{\star *}$ & $0.8^{*}$ & $0.001^{*}$ & $0.0005^{\star *}$ & $0.00008^{*}$ & $0.0003^{* *}$ \\
\hline $\mathrm{N}$ rate * variety & 9 & $0.9 \mathrm{~ns}$ & $0.5 \mathrm{~ns}$ & $0.2 \mathrm{~ns}$ & $0.0004 \mathrm{~ns}$ & $0.00005 n s$ & $0.00001 \mathrm{~ns}$ & $0.00008 \mathrm{~ns}$ \\
\hline Residual error & 45 & 0.8 & 0.1 & 0.2 & 0.0003 & 0.0001 & 0.00001 & 0.0001 \\
\hline \multicolumn{5}{|l|}{$\mathrm{N}$ rate, $\mathrm{kg} \mathrm{ha}^{-1}$} & \multicolumn{3}{|c|}{ means, Mg ha ${ }^{-1}$} & \\
\hline 0 & & 3.51 & 1.50 & 1.99 & 0.050 & 0.032 & 0.011 & 0.043 \\
\hline 30 & & 3.97 & 1.84 & 1.74 & 0.059 & 0.041 & 0.010 & 0.051 \\
\hline 60 & & 4.68 & 2.05 & 1.77 & 0.071 & 0.047 & 0.012 & 0.059 \\
\hline 120 & & 4.93 & 2.16 & 1.74 & 0.088 & 0.053 & 0.013 & 0.066 \\
\hline SED & & 0.32 & 0.14 & 0.15 & 0.006 & 0.004 & 0.001 & 0.004 \\
\hline \multicolumn{9}{|l|}{ Variety: } \\
\hline Chisholm & & 4.68 & 2.23 & 1.79 & 0.073 & 0.049 & 0.010 & 0.059 \\
\hline Karl & & 4.06 & 1.69 & 1.55 & 0.066 & 0.040 & 0.10 & 0.050 \\
\hline 2180 & & 3.48 & 1.58 & 2.10 & 0.056 & 0.037 & 0.015 & 0.052 \\
\hline TAM W-101 & & 4.85 & 2.05 & 1.81 & 0.074 & 0.047 & 0.010 & 0.057 \\
\hline SED & & 0.32 & 0.14 & 0.15 & 0.006 & 0.004 & 0.001 & 0.004 \\
\hline \multicolumn{9}{|l|}{ Contrasts: } \\
\hline $\mathrm{N}$ rate linear & 1 & $* *$ & $* *$ & ns & $* \star$ & ** & $* *$ & ** \\
\hline $\mathrm{N}$ rate quadratic & 1 & ns & ns & ns & ns & ns & ns & ns \\
\hline
\end{tabular}

${ }^{*},{ }^{* *}$ Significant at 0.05 and 0.01 probability levels, respectively. SED - standard error of the difference between two equally replicated means, ns - not significant. 
Table 4. Analysis of Variance, Means and Comparisons for Yield and Nitrogen Uptake, Perkins, OK 1995.

\begin{tabular}{|c|c|c|c|c|c|c|c|c|}
\hline & \multirow[b]{3}{*}{ df } & Forage & Grain & Straw & Forage & Grain & Straw & $($ Grain + Straw) \\
\hline & & -------- & ld, Mg ha & ---- & \multirow{2}{*}{\multicolumn{4}{|c|}{ nitrogen uptake, Mg ha' ${ }^{-1}$}} \\
\hline $\begin{array}{l}\text { Source of variation } \\
\text { Replication }\end{array}$ & & \multicolumn{3}{|c|}{ 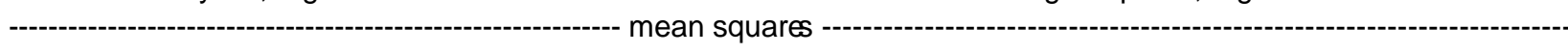 } & & & & \\
\hline $\mathrm{N}$ rate & 3 & $1.9 \mathrm{~ns}$ & $0.2^{* *}$ & $0.8^{* *}$ & $0.003^{* *}$ & $0.0004^{\star *}$ & $0.0002^{* *}$ & $0.001^{* *}$ \\
\hline Variety & 4 & $1.7 \mathrm{~ns}$ & $0.3^{\star *}$ & $5.2^{\star *}$ & $0.0003 \mathrm{~ns}$ & $0.00006^{*}$ & $0.0004^{* *}$ & $0.0004^{* *}$ \\
\hline $\mathrm{N}$ rate * variety & 12 & $1.0 \mathrm{~ns}$ & $0.06^{*}$ & $0.5^{\star \star}$ & $0.0004 \mathrm{~ns}$ & $0.00004 n s$ & $0.00008^{*}$ & $0.0002^{* *}$ \\
\hline \multicolumn{9}{|l|}{$\mathrm{N}$ rate, $\mathrm{kg} \mathrm{ha}^{-1}$} \\
\hline 0 & & 2.96 & 0.83 & 1.50 & 0.052 & 0.021 & 0.014 & 0.036 \\
\hline 45 & & 3.56 & 0.93 & 1.46 & 0.066 & 0.026 & 0.016 & 0.042 \\
\hline 90 & & 3.40 & 0.88 & 1.57 & 0.071 & 0.027 & 0.018 & 0.045 \\
\hline 180 & & 3.80 & 1.12 & 1.98 & 0.087 & 0.034 & 0.023 & 0.057 \\
\hline SED & & 0.34 & 0.07 & 0.13 & 0.007 & 0.002 & 0.002 & 0.003 \\
\hline Chisholm & & 3.31 & 0.90 & 1.28 & 0.063 & 0.026 & 0.016 & 0.041 \\
\hline Karl & & 3.19 & 0.87 & 1.17 & 0.065 & 0.026 & 0.012 & 0.039 \\
\hline 2180 & & 3.82 & 1.07 & 1.21 & 0.075 & 0.032 & 0.015 & 0.047 \\
\hline TAM W-101 & & 2.92 & 0.86 & 1.68 & 0.066 & 0.024 & 0.018 & 0.042 \\
\hline Longhorn & & 3.95 & 1.02 & 2.80 & 0.077 & 0.027 & 0.028 & 0.055 \\
\hline SED & & 0.38 & 0.08 & 0.15 & 0.008 & 0.002 & 0.002 & 0.003 \\
\hline \multicolumn{9}{|l|}{ Contrasts: } \\
\hline $\mathrm{N}$ rate linear & 1 & * & $\star *$ & $* *$ & $* *$ & $* *$ & $* *$ & ** \\
\hline $\mathrm{N}$ rate quadratic & 1 & ns & ns & ns & ns & ns & ns & ns \\
\hline
\end{tabular}

*, ${ }^{* *}$ Significant at 0.05 and 0.01 probability levels, respectively. SED - standard error of the difference between two equally replicated means, ns - not significant. 
Table 5. Analysis of Variance, Means and Comparisons for Nitrogen Use Efficiency Components, Stillwater, OK 1994.

\begin{tabular}{|c|c|c|c|c|c|c|c|c|}
\hline & & $\begin{array}{l}\text { Protein } \\
\%\end{array}$ & $\begin{array}{l}\mathrm{N} \text {-use } \\
\text { efficiency } \\
\text { (Gw/Ns) }\end{array}$ & $\begin{array}{l}\mathrm{N} \text {-uptake } \\
\text { efficiency } \\
(\mathrm{Nt} / \mathrm{Ns})\end{array}$ & $\begin{array}{l}\mathrm{N} \text {-utilization } \\
\text { efficiency } \\
\text { (Gw/Nt) }\end{array}$ & $\begin{array}{l}\text { Fraction of } \\
\mathrm{N} \text { translocated } \\
\text { to grain }(\mathrm{Ng} / \mathrm{Nt})\end{array}$ & $\begin{array}{l}\text { Grain yield/ } \\
\text { grain N } \\
(\mathrm{Gw} / \mathrm{Ng})\end{array}$ & $\begin{array}{l}\text { N loss } \\
\left(\mathrm{kg} \mathrm{ha}^{-1}\right) \\
(\mathrm{Na}-\mathrm{Nh})\end{array}$ \\
\hline Source of variation & df & ---------- & - & -----------. & --- mean squa & ----------------- & -------------- & - \\
\hline Replication & 3 & $102.1^{* *}$ & $48.8 n s$ & $0.20^{* *}$ & $366.9^{* *}$ & $0.01^{* *}$ & $442.4^{\star *}$ & $3233.8^{* *}$ \\
\hline $\mathrm{N}$ rate & 3 & $36.6^{* \star}$ & $7713.4^{\star *}$ & $5.47^{\star *}$ & 24.7ns & $0.01^{* *}$ & $109.3^{\star *}$ & $710.3^{*}$ \\
\hline Variety & 3 & $10.0 \mathrm{~ns}$ & $515.6^{\star *}$ & $0.11^{*}$ & $159.1^{* *}$ & $0.04^{\star *}$ & $38.3 n s$ & 572.6ns \\
\hline $\mathrm{N}$ rate * variety & 9 & $11.4 \mathrm{~ns}$ & $105.4 \mathrm{~ns}$ & $0.03 n s$ & $11.9 \mathrm{~ns}$ & $0.002 n s$ & $11.6 n s$ & $372.3 \mathrm{~ns}$ \\
\hline \multicolumn{9}{|l|}{$\mathrm{N}$ rate, $\mathrm{kg} \mathrm{ha}^{-1}$} \\
\hline 0 & & 12.1 & 0 & 0 & 35.4 & 0.74 & 47.6 & 7.7 \\
\hline 30 & & 12.9 & 61.5 & 1.7 & 36.2 & 0.80 & 45.3 & 8.2 \\
\hline 60 & & 13.1 & 34.2 & 1.0 & 35.7 & 0.80 & 44.6 & 12.9 \\
\hline 120 & & 14.1 & 18.0 & 0.5 & 33.4 & 0.81 & 41.2 & 22.1 \\
\hline SED & & 0.51 & 2.41 & 0.07 & 1.38 & 0.02 & 1.61 & 5.68 \\
\hline Chisholm & & $12.5 a$ & 46.2 & 1.2 & 38.2 & 0.8 & $46.5 a$ & 13.9 \\
\hline Karl & & $13.4 \mathrm{a}$ & 34.0 & 1.0 & 34.3 & 0.8 & $43.1 \mathrm{a}$ & 15.9 \\
\hline 2180 & & $13.5 a$ & 31.5 & 1.0 & 31.1 & 0.7 & $43.8 \mathrm{a}$ & 4.0 \\
\hline TAM W-101 & & $12.9 a$ & 39.8 & 1.1 & 37.1 & 0.8 & $45.3 a$ & 17.1 \\
\hline SED & & 0.51 & 2.41 & 0.07 & 1.38 & 0.02 & 1.61 & 5.68 \\
\hline \multicolumn{9}{|l|}{ Contrasts: } \\
\hline $\mathrm{N}$ rate linear & & $* *$ & ** & ** & ns & ** & ** & $\star *$ \\
\hline $\mathrm{N}$ rate quadratic & & ns & ** & $* *$ & ns & * & ns & ns \\
\hline
\end{tabular}

* ${ }^{* *}$ Significant at 0.05 and 0.01 probability levels, respectively. $\mathrm{Gw}=$ grain weight; $\mathrm{Ns}=\mathrm{N}$ supply; $\mathrm{Na}=\mathrm{N}$ accumulated in plant at anthesis; $\mathrm{Nt}=$ total $\mathrm{N}$ in plant at maturity; $\mathrm{Ng}=\mathrm{N}$ accumulated in grain at harvest; $\mathrm{Nh}=\mathrm{N}$ accumulated in plant at harvest. SED - standard error of the difference between two equally replicated means, ns - not significant. 
Table 6. Analysis of Variance, Means and Comparisons for Nitrogen Use Efficiency Components, Perkins, OK 1995.

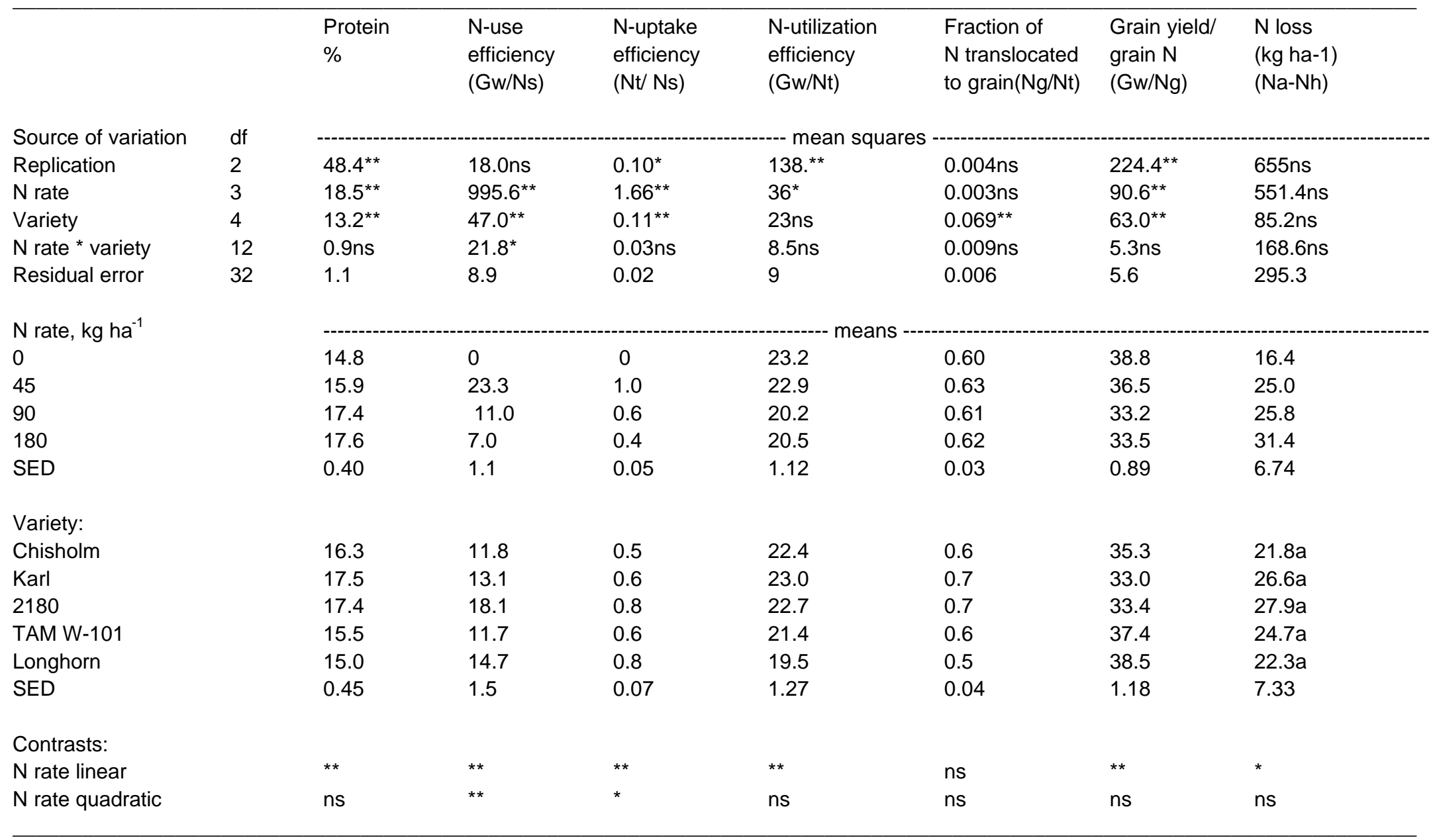

${ }^{*},{ }^{* *}$ Significant at 0.05 and 0.01 probability levels, respectively. $\mathrm{Gw}=$ grain weight; $\mathrm{Ns}=\mathrm{N}$ supply; $\mathrm{Na}=\mathrm{N}$ accumulated in plant at anthesis; Nt $=$ total $\mathrm{N}$ in plant at maturity; $\mathrm{Ng}=\mathrm{N}$ accumulated in grain at harvest; $\mathrm{Nh}=\mathrm{N}$ accumulated in plant at harvest. Means followed by same letter are not significantly different at 0.05 probability level. SED - standard error of the difference between two equally replicated means. 
Table 7. Means for Yield and Components of Nitrogen Use Efficiency at various Nitrogen Rates, Perkins, OK 1995.

\begin{tabular}{|c|c|c|c|c|c|}
\hline & Grain yield & Straw yield & $\begin{array}{l}\text { Straw N } \\
\text { uptake }\end{array}$ & $\begin{array}{l}\text { Grain + Straw N } \\
\text { uptake }\end{array}$ & $\begin{array}{l}\mathrm{N} \text {-use } \\
\text { efficiency }\end{array}$ \\
\hline \multicolumn{6}{|l|}{$\underline{0 \mathrm{~kg} \mathrm{~N} \mathrm{ha}^{-1}}$} \\
\hline Chisholm & 0.89 & 1.47 & 0.019 & 0.042 & - \\
\hline Karl & 0.86 & 1.19 & 0.011 & 0.035 & - \\
\hline 2180 & 0.64 & 0.87 & 0.011 & 0.030 & - \\
\hline TAM W-101 & 0.87 & 1.85 & 0.017 & 0.038 & - \\
\hline Longhorn & 0.81 & 1.89 & 0.014 & 0.033 & - \\
\hline \multicolumn{6}{|l|}{$45 \mathrm{~kg} \mathrm{~N} \mathrm{ha}^{-1}$} \\
\hline Chisholm & 0.93 & 1.34 & 0.013 & 0.040 & 23 \\
\hline Karl & 0.78 & 0.72 & 0.001 & 0.032 & 19 \\
\hline 2180 & 1.28 & 1.49 & 0.017 & 0.052 & 32 \\
\hline TAM W-101 & 0.76 & 1.28 & 0.016 & 0.037 & 19 \\
\hline Longhorn & 0.91 & 2.46 & 0.026 & 0.048 & 23 \\
\hline \multicolumn{6}{|l|}{$90 \mathrm{~kg} \mathrm{~N} \mathrm{ha}^{-1}$} \\
\hline Chisholm & 0.76 & 0.85 & 0.011 & 0.034 & 10 \\
\hline Karl & 0.91 & 1.44 & 0.016 & 0.044 & 11 \\
\hline 2180 & 1.10 & 1.16 & 0.014 & 0.050 & 14 \\
\hline TAM W-101 & 0.79 & 1.74 & 0.019 & 0.042 & 10 \\
\hline Longhorn & 0.91 & 3.22 & 0.035 & 0.061 & 11 \\
\hline \multicolumn{6}{|l|}{$180 \mathrm{~kg} \mathrm{~N} \mathrm{ha}^{-1}$} \\
\hline Chisholm & 1.01 & 1.50 & 0.018 & 0.049 & 6 \\
\hline Karl & 0.95 & 1.44 & 0.017 & 0.046 & 6 \\
\hline 2180 & 1.13 & 1.19 & 0.016 & 0.051 & 73 \\
\hline TAM W-101 & 1.03 & 1.83 & 0.022 & 0.055 & 6 \\
\hline Longhorn & 1.41 & 3.78 & 0.039 & 0.078 & 9 \\
\hline SED & 0.16 & 0.29 & 0.004 & 0.006 & 2.4 \\
\hline
\end{tabular}

$\mathrm{GW}=$ grain weight; $\mathrm{Ns}=\mathrm{N}$ supply; $\mathrm{Na}=\mathrm{N}$ accumulated in plant at anthesis; $\mathrm{Nt}=$ total $\mathrm{N}$ in plant at maturity; $\mathrm{Ng}=\mathrm{N}$ accumulated in grain at harvest; $\mathrm{Nh}=\mathrm{N}$ accumulated in plant at harvest. 


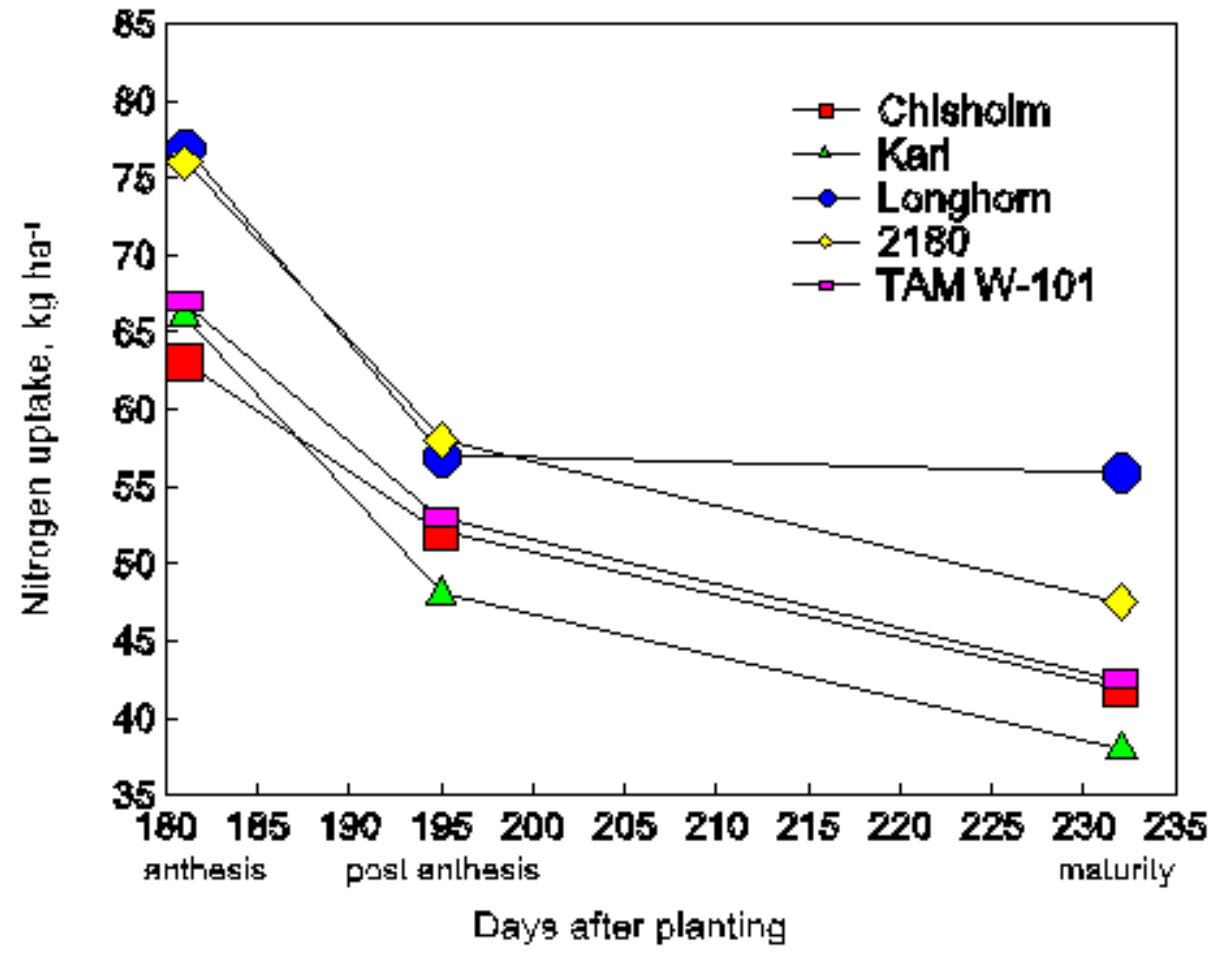

Figure 1. Change in total nitrogen uptake from anthesis to maturity in several winter wheat varieties, Perkins, OK 1995. 
